\title{
A MATERNIDADE \\ E A PROSTITUIÇÃO: \\ UMA ANÁLISE DISCURSIVA \\ DE ENTREVISTAS \\ COM GAROTAS \\ DE PROGRAMA
}

\section{LA MATERNIDAD Y LA PROSTITUCIÓN: UN ANÁLISIS DISCURSIVO DE ENTREVISTAS CON PROSTITUTAS}

\section{MOTHERHOOD AND PROSTITUTION: A DISCURSIVE ANALYSIS OF INTERVIEWS WITH PROSTITUTES}

Mirielly Ferraça*

Universidade Estadual de Campinas

\begin{abstract}
RESUMO: A partir de entrevistas realizadas com quatro garotas de programa e com base no aporte teórico da Análise de Discurso de orientação francesa, este artigo coloca em discussão um dos argumentos apresentados para justificar a entrada na prostituição: os filhos. No jogo discursivo, as entrevistadas exaltam o lugar materno ocupado, descrevendo o quão boas mães são, tecendo a defesa da escolha que fizeram. Assim, a maternidade é usada como um redirecionamento discursivo, uma tentativa de apagar o lugar da prostituta ocupado, intensificando discursivamente o sacrifício materno realizado. Entretanto, apesar do aparente controle dos sentidos, a contradição, constitutiva da linguagem, se instala e outros sentidos escapam.
\end{abstract}

PALAVRAS-CHAVE: Prostituição. Entrevistas. Maternidade. Análise do Discurso. Interdiscurso.

RESUMEN: A partir de entrevistas realizadas con cuatro prostitutas y basándose en el aporte teórico del Análisis de Discurso francés, este artículo pone en discusión uno de los argumentos presentados para justificar la entrada en la prostitución: los hijos. En el juego discursivo, las entrevistadas exaltan el lugar materno que ocupan, describiendo las buenas madres que son, tejiendo la defensa de lo que han elegido. Así, la maternidad es usada como un redireccionamiento discursivo, una tentativa de apagar el lugar de prostituta ocupado por ellas, intensificando discursivamente el sacrificio materno realizado. Sin embargo, pese al aparente control de los sentidos, la contradicción, constitutiva del lenguaje, se instala y otros sentidos escapan.

PALABRAS CLAVE: Prostitución. Entrevistas. Maternidad. Análisis del Discurso. Interdiscurso.

ABSTRACT: From interviews made with four prostitutes, and based on the theoretical framework of the French-oriented discourse analysis, this article discusses one of the arguments presented to justify the decision of starting to work as a prostitute: children. In

* Doutoranda em Linguística pela Universidade Estadual de Campinas (UNICAMP), com bolsa auxílio CAPES. Mestrado e Graduação em Letras pela Universidade Estadual do Oestedo Paraná (UNIOESTE). E-mail: miriellyferraca@gmail.com. 
the discursive game, the women interviewed exalt the occupied maternal place, describing how good they are as mothers, weaving the defense of the option they chose. With that, maternity is used as a speech redirection, a way to erase the prostitute spot, discursively intensifying the sacrifice of motherhood. Although, despite the apparent control of the senses, the contradiction, constitutive of language, installs itself, and other senses escape.

KEYWORDS: Prostitution. Interviews. Motherhood. Discourse Analysis. Inter-discourse.

\section{INTRODUÇÃO}

A história (re)conta que o comércio sexual existiu em várias sociedades, sob diferentes formas e em diversas épocas. O sexo livre e a sua venda foram aceitos, incentivados, repudiados, proibidos e considerados pecado. Por outro lado, nem sempre o sexo civil, entendido como a relação sexual entre esposa e marido, foi incentivado, nem sempre foi regra social, nem sempre foi diretriz religiosa. O que, de fato, há na história são idas e vindas de uma profusão de discursos que foram ora aceitos, ora negados, ora apagados, ora ressignificados.

Resquícios de outras épocas vêm à tona por meio do interdiscurso e da memória discursiva, delineados a partir da sobredeterminação das condições de produção, que afetam o intradiscurso, convergindo num misto do mesmo e do "diferente"l. $\mathrm{O}$ mesmo é dito de outra forma, já que a "[...] condição de existência dos sujeitos e dos sentidos [...]" é "[...] constituída na relação tensa entre paráfrase e polissemia [...]" (ORLANDI, 2001, p. 37). Pelo retorno da memória e do interdiscurso, é possível perceber na história o movimento discursivo, as idas e vindas de um discurso dito em outro lugar, tendo a repetição, o conflito e a tensão (mas, sobretudo, a paráfrase) como aspecto constitutivo da linguagem. Nesse contexto, conforme afirma Lagazzi, (1988, p. 9, grifos no original) "faz-se necessário, contudo [...] explicitar essa tensão, mostrar que ela é historicamente determinada [...]".

Neste trabalho, garotas de programa são as protagonistas da pesquisa. A partir de suas histórias, analisa-se que efeitos de sentido ecoam sobre a milenar venda do corpo e se seus enunciados reforçam os dizeres cristalizados sobre essa prática. São histórias de mulheres que encontram na venda de sexo um jeito (fácil ou não) de ganhar dinheiro. Cada uma das entrevistadas narra peculiaridades de suas histórias, mas, de uma forma ou de outra, os caminhos das quatro acabam se cruzando no entrelaçar de uma memória que se repete. Nos depoimentos colhidos, nota-se a materialização da repetição de um discurso que precede aos sujeitos, que, entretanto, por si só não definem inteiramente seus dizeres, dado que o sujeito é histórico e imprime sentidos a partir das suas condições de produção. Há, portanto, nessa confluência de sentidos, vozes já ditas que se misturam com o aqui e o agora, o interdiscurso no intradiscurso, e este naquele.

Na conversa realizada, as entrevistadas apontam os caminhos que as levaram a prostituição, como o divórcio, o sustento dos filhos, a falta de dinheiro, a falta de emprego, a influência de amigas e o próprio destino. Mas, especificamente, neste artigo, o foco estará nas Sequências Discursivas (SDs) que revelam os filhos como impulsionadores para a entrada das garotas para o meretrício. Os filhos, como se verá, são o motivo para elas estarem ali, na boate, vendendo sexo por dinheiro; eles são apresentados como os "culpados" pela "escolha" (ou falta dela) que fizeram. Discursivamente, as justificativas colocam em movimento o lugar materno, aquele em que se sacrificar pelos filhos (seja qual sacrifício for) redime-as perante olugar ocupado na prostituição. Em contrapartida, como se verá no decorrer do trabalho, no embate e na contradição discursiva o mesmo discurso redentor falha e sobrepõe-se ao lugar da prostituta, ecoando os sentidos morais cristalizados em torno da prática.

\section{PORTO DAS SEREIAS: METODOLOGIA E PESQUISA DE CAMPO}

O fio condutor para o desenvolvimento desta pesquisa éa Análise do Discurso francesa, pressuposto teórico que movimenta análises discursivas por meio do enlace da Linguística, da Psicanálise e do Materialismo Histórico. É a partir da e na linguagem que o sujeito se constitui, dentro de um contínuo processo ideológico e, assim, é por meio da materialidade linguística que é possível observar o

${ }^{1} \mathrm{O}$ diferente utilizando aqui se refere à ressignificação e não ao novo, dado que os sentidos se movem, mas não nascem completamente outros. 
funcionamento da língua, indissociada da história e da ideologia: "A linguagem configura as pistas para que possamos chegar um pouco mais perto do sujeito, e a Análise do Discurso possibilita que o conhecimento constitua-se além do 'achar' de cada pesquisador e fora de qualquer modelo pré-concebido" (LAGAZZI, 1988, p. 51).

Como já mencionado, este artigo parte de sequências discursivas selecionadas a partir de entrevistas realizadas com garotas de programa. Ressalta-se que este trabalho foi aceito pelo Comitê de Ética em Pesquisa (CEP)², da Universidade Estadual do Oeste do Paraná, e está inscrito na Plataforma Brasil, base nacional unificada de pesquisa com seres humanos.

As entrevistas foram realizadas em 2012, em uma boate da cidade de Cascavel-Paraná. O local foi selecionado por meio de uma amostragem não probabilística por acessibilidade, já que se trata de um trabalho qualitativo. Foram quatro entrevistadas e duas visitas à casa, sendo uma entrevista feita no primeiro dia e outras três no segundo. Optou-se por uma entrevista semi-estruturada, método que permite explorar informações não previstas durante a elaboração das perguntas; para a coleta de dados utilizou-se um gravador. Durante a transcrição das entrevistas, procurou-se evitar correções ortográficas, gramaticais ou inserção livre de complementos, buscando aproximar-se da forma como a entrevista oral ocorreu, com suas pausas, repetições e reticências.

Apesar de haver pouco envolvimento do pesquisador na transcrição dos dados, vale ressaltar que uma pesquisa de campo, principalmente a que utiliza entrevistas, conta com a interferência do pesquisador durante o processo de definição e seleção e, principalmente, durante a coleta, já que o sujeito-pesquisador não escapa aos olhos dos entrevistados. É impossível apagar o lugar que o entrevistador ocupa durante a entrevista e a imagem que se tem do papel que ele exerce; entretanto tais interferências fazem parte da pesquisa, não sendo este um problema metodológico. Como defende Flick (2009), o pesquisador passa a ser parte da constituição dos sentidos que se obterá com o trabalho:

De modo diferente da pesquisa quantitativa, os métodos qualitativos consideram a comunicação do pesquisador em campo como parte explícita da produção de conhecimento, em vez de simplesmente encará-la como uma variável a interferir no processo. A subjetividade do pesquisador, bem como daqueles que estão sendo estudados, tornam-se parte do processo de pesquisa. As reflexões dos pesquisadores sobre suas próprias atitudes e observações em campo, suas impressões, irritações, sentimentos, etc., tornam-se dados em si mesmos, constituindo parte da interpretação e são, portanto, documentadas em diários de pesquisa ou em protocolos de contexto (FLICK, 2009, p. 25, grifos meus).

Considera-se, também, que as entrevistadas realizam durante o processo discursivo uma série de projeções imaginárias de si mesmas, enquanto sujeitos discursivos, assim como do pesquisador. Tais jogos imaginários são imprescindíveis para a constituição do discurso, pois, em um movimento contínuo, como em um jogo de espelhos, ocorrerá entre interlocutores uma sucessão de imagens: "[...] aquele que obedece faz uma imagem de si mesmo, do lugar que ocupa na relação com o outro, desse outro que exerce o poder, do lugar ocupado por este, e assim sucessivamente [...]" (LAGAZZI, 1988, p. 38-39). Nesse sentido, o interlocutor realizará as mesmas projeções imaginárias. Diante de tais relações, o sujeito acredita poder obter o controle de seu discurso, achando-se dono de si:

Segundo o mecanismo da antecipação, todo sujeito tem a capacidade de experimentar, ou melhor, de colocar-se no lugar em que o seu interlocutor 'ouve' suas palavras. Ele antecipa-se assim a seu interlocutor quanto ao sentido que as suas palavras produzem. Esse mecanismo regula a argumentação, de tal forma que o sujeito dirá de um modo, ou de outro, segundo o efeito que pensa produzir no seu ouvinte (ORLANDI, 2001, p. 39, grifos meus).

Porém, sabe-se que o sujeito não domina seu dizer. Ele pode, eventualmente, realizar substituições a fim de usar a língua a seu favor, mas não consegue permanecer no controle o tempo todo e nem mesmo controlar os efeitos de sentido que seu enunciado pode suscitar. As entrevistadas não realizam essas projeções e nem mesmo buscam obter o controle de seus discursos somente diante do pesquisador e, exclusivamente, quando exercem o papel de objetos de pesquisa, mas realizam esse jogo de imagens diante de

${ }^{2}$ Processo: CAAEE 03230912.8.0000.0107 
qualquer outra situação discursiva e diante de qualquer outro sujeito (dependendo das condições de produção e de quem é o interlocutor, poderá haver uma tentativa maior ou menor de controle, mas as relações imaginárias ocorrerão de um jeito ou de outro, pois o mecanismo imaginário é parte constitutiva do processo enunciativo). Dessa forma, encobrimentos e tentativas de esconder certos efeitos podem ser realizados em quaisquer outras condições de produção, de forma mais ou menos consciente.

Salienta-se que as entrevistadas não serão identificadas com seus verdadeiros nomes, e nem mesmo será divulgado o nome real da boate em que estavam, respeitando o anonimato das fontes e os preceitos éticos estabelecidos pelo CEP. Os nomes das garotas de programa utilizados neste trabalho foram sugeridos por elas mesmas e a boate será chamada Porto das Sereias ${ }^{3}$, nome fictício, criado para substituir o nome original.

Distante do perímetro urbano, mas propositalmente bem localizado para quem entra e sai da cidade e intencionalmente bem localizado para quem deseja sexo clandestino, localiza-se o Porto das Sereias, boate que iniciou suas atividades em 1983 e permanece até hoje no mesmo endereço, às margens de Cascavel-PR. Investir no empreendimento na época, segundo um dos sócios, era receber retorno monetário mais rápido. Dinheiro fácil não se restringe, portanto, somente às garotas que vendem sexo, mas também a quem está nos bastidores e se vale delas. Depois de 1989, começou a oscilação no movimento da casa. Hoje, a circulação de clientes e garotas aumenta quando há grandes eventos na cidade. O período de safra, segundo o proprietário, é quando acontece o Show Rural, principal evento de agronegócio de Cascavel e região, que recebe quase 200 mil visitantes. Nessa época, a casa fica cheia: cerca de 40 meninas passam a viver no Porto das Sereias. Antigamente, a casa funcionava de segunda a sábado, pois não havia tantas opções na cidade para sair à noite. Hoje, a casa abre de segunda a sexta e aos sábados esporadicamente, quando há swing.

Mônica, Ana Paula, Carol e Duda. Quatro entrevistadas são as protagonistas desta pesquisa e o enredo é construído por elas, pelas formações discursivas e ideológicas que as determinam e pelas condições de produção em que a história foi escrita. Quatro diferentes histórias que, de certa forma, se encontram. Apesar de cada uma passar por situações diversas até se tornarem garotas de programa, de possuírem ex-relações conjugais distintas, de terem relações familiares diferentes, os laços de suas vidas se cruzam em nós comuns, constituem os pontos de encontro de histórias que se repetem sobre a venda do corpo.

\section{OS FINS JUSTIFICAM OS MEIOS: FILHOS, O BEM MAIOR}

Movidas pela injunção do interdiscurso, da memória, das formações discursivas das quais compartilham, pelos dizeres perpetuados sobre a prostituição e por todo o estigma que há sobre a venda do corpo, percebe-se, ao analisar a materialidade linguística selecionada, que as garotas de programa precisam justificar por que fazem o que fazem, imputando a responsabilidade ao outro. As entrevistadas usam os filhos, a separação e a falta de emprego para se desculparem e amenizar o estigma que recai sobre a prática exercida. Neste artigo, selecionaram-se somente recortes discursivos que afirmam ser os filhos a razão de estarem na noite.

As garotas entrevistadas apresentam várias justificativas com a intenção, seja ela consciente ou não, de se defenderem das acusações (nem tão) implícitas que existem socialmente contra elas. Em toda a entrevista, há uma matriz de sentido organizadora que pode ser reunida sob a tutela de: "faço algo errado e devo me justificar e apresentar boas razões para estar fazendo o que faço, senão posso ser julgada de forma equivocada" (ou algo semelhante). São apresentadas boas razões (mas não boas o suficiente, já que não rompem com o imaginário reinante) que buscam explicar o porquê de elas terem feito a escolha que fizeram, visando a convencer o interlocutor de que, apesar de se prostituir ser considerado errado, como elas mesmas afirmam, ainda assim é justificável. A culpa está sempre no outro, seja ele um motivo mais ou menos nobre: nunca elas mesmas são as culpadas. Como se vê, elas se submetem, sem falhas, à condição de ter que justificar o injustificável: tentativa vã de se tornar aceitável perante aos valores morais perpetuados.

\footnotetext{
${ }^{3}$ Relaciona-se porto com o lugar de passagem de homens e mulheres que buscam sexo e local igualmente de passagem para as sereias que desembarcam para vender sexo. Formada por uma imagem híbrida, a sereia é, em sua completude, a soma da incompletude das partes de que é feita: metade mulher, metade peixe. Assim é a prostituta, dividida entre mulher idealizada e garota de programa (re)negada, em que cada metade experiencia um lugar diferenciado, mas cada lugar não pode ser ocupado em sua plenitude.

4 "Prática sexual conjunta de dois ou mais casais" (HOUAISS, 2004).
} 
Para defesa, elas mostram que ocupam outros lugares na trama social e se apoiam neles como mudança de foco discursivo. Segundo Pêcheux (1997), os protagonistas do discurso não são indivíduos; eles passam pelo crivo da injunção que impõe a forma de vida de lugares estabelecidos na trama social. Com essas imagens, tem-se a projeção de posições pré-determinadas, podendo o sujeito ocupar uma ou mais e, ainda, transitar entre tais posições, ora usando o discurso de uma formação discursiva, ora inserindo-se em outra, mas sempre sofrendo as suas injunções. No caso em estudo, percebe-se que as formações discursivas não são fechadas: são permeadas por outros discursos, num constante embate e absorção de sentidos. As entrevistadas confirmam ser profissionais do sexo, mas, por tratar-se de uma atividade condenada, apoiam-se em outros papéis ${ }^{5}$, buscando justificar suas escolhas. As entrevistadas são x (garotas de programa), mas porque são, antes de tudo, y: mães. Segundo Roberts (1998), a maternidade é um dos principais motivos que impulsiona a entrada para a prostituição:

\begin{abstract}
As prostitutas não pensam apenas nelas próprias quando trabalham na indústria do sexo - a maioria delas também é mãe. Ganhar dinheiro suficiente para criar os filhos independentemente dos homens é um tema que surge continuamente nas motivações das prostitutas (ROBERTS, 1998, p. 384, grifos meus).
\end{abstract}

Dessa forma, considerando que antes de elas serem x (garotas de programa), elas afirmam que são y (mãe, ou...), percebe-se que as entrevistadas preferem mostrar, realçar ou ressaltar o papel materno que desempenham e que o sustento dos filhos justifica a atividade que exercem, buscando, por meio do deslize discursivo, uma forma de justificarem porque são x (garotas de programa).

(SD 03) Minha filha tem 14 anos, né? E meu filho tem 12. E... é o meu foco, na verdade, né? Meu e de todas daqui. Assim, trabalho assim nessa vida pra dar o melhor pros meus filhos (Duda - grifos meus).

Considerando a SD 03, os filhos são o foco das entrevistadas: de todas. Elas trabalham na vida para darem o melhor para os filhos. Mas, afinal, que mãe não busca dar o melhor para os filhos? O discurso materno passa não só a ser usado como justificativa, mas também tem a meta de comover o interlocutor e de redirecionar o foco discursivo. Apaga-se o fato de que elas também se beneficiariam com a prostituição, pois, na SD 03, é afirmado que o melhor é somente e exclusivamente direcionado aos filhos. Silencia-se que elas se prostituem para e por elas, e não só pelos filhos. Além disso, pode-se afirmar que o uso do pronome possessivo meu e minha, de certa maneira, aponta para uma contradição entre elas afirmarem que se prostituem pelos filhos, pois, ao mesmo tempo, estão ali a serviço de si mesmas (talvez até por terem prazer ao realizar a atividade, visto ser a prostituição o lugar da manifestação do desejo, ainda que se negue tal prazer). Tal qual ato falho, os pronomes revelam a serviço de quem estão ali: $m e u s$, minhas, isto é, elas mesmas.

Além disso, também pode ser que exista a satisfação de verem a si próprias como pessoas que se encaixam, ainda que em partes, na imagem idealizada da mãe, da progenitora que, em tese, doar-se-ia para a sua descendência, quando, de fato, o estar pelos filhos seria estar por si próprias, uma vez que eles seriam a continuidade de si.

O discurso materno que vê nos filhos o bem maior passa a ser uma das justificativas utilizadas para isentá-las da culpa da venda do sexo, já que esta atividade é realizada como sacrifício, em prol do outro. De certo modo, doa-se a vida pelo outro, o que as assemelha a Cristo, que aceitou a crucificação pelo próximo, colocando-as ao lado do divino (e por deslize semântico, do certo, do bom, do aceitável). Doar-se pelo outro parece ter como objetivo isentá-las ou redimi-las do julgamento social e ser mãe lhes fornece o respaldo necessário para tal tento. Vale salientar que há uma contradição entre serem garotas de programa e mães que fazem tudo pelos filhos, pois se eles são o motivo para que elas ingressem na prostituição, se são eles que as empurram para a venda de sexo, por meio dessa lógica, eles deixam de ser o bem maior para se tornarem o mal, já que socialmente vender o corpo é considerado errado, ruim, mal (ou ainda pecado).

Ainda na SD 03, quando Duda afirma que deseja dar o melhor para os filhos, pode-se associar o termo a melhores condições financeiras, pois o melhor, na maioria das vezes, relaciona-se com o mais caro financeiramente: melhores escolas, roupas, calçados etc. Na formação capitalista, dar essas condições aos filhos só seria possível com um trabalho que oferecesse uma remuneração mais

${ }^{5} \mathrm{O}$ termo papéis é usado neste trabalho não no sentido de representação, mas como forma de dizer que elas se apoiam em outros lugares, outras posições. 
elevada, sendo a prostituição um caminho mais curto para se alcançar isso. O discurso reinante reafirma que boas mães (e bons pais) devem oferecer o melhor e nunca o pior aos filhos, e, assim, a qualidade de boa mãe se faz presente novamente no discurso de Duda. Para proporcionar esse melhor (associado a melhores condições financeiras), no caso de Duda, só é possível trabalhando com a venda de sexo.

Elas transitam em duas formações discursivas diversas: ser mãe, dentro do modelo sagrado de amor eterno, dedicação e abdicação, e ser prostituta, a nefasta que vende sexo por dinheiro, contrapondo-se ao modelo idílico familiar. Note-se que, no caso das entrevistadas, a primeira formação discursiva prepondera sobre a segunda. Elas circulam entre as duas Formações Discursivas (FD), mas para justificar o erro utilizam como respaldo a formação materna, idealizada e defendida socialmente, como contextualiza Giddens (1995, p. 53, grifos meus):

\begin{abstract}
A idealização da mãe foi parte integrante da moderna construção da maternidade, e sem dúvida alimentou diretamente alguns dos valores propagados sobre o amor romântico. A imagem da 'esposa mãe' reforçou um modelo de 'dois sexos' das atividades e dos sentimentos.
\end{abstract}

O amor materno consolida o amor romântico e a idealização do formato burguês de família, em que se tem na mulher a responsável pelo funcionamento do lar, é ela quem cuida dos filhos, da casa e do marido. As quatro entrevistadas são divorciadas e todas detêm a guarda dos filhos, com exceção de Duda, que entregou as crianças ao marido:

(SD 04) Então quando eu vi que, assim, eu tava sozinha mesmo, meus filhos pediam as coisas [...]. Então, o que aconteceu, aí quando eu vi, assim, que eu não queria deixar meus filhos com pessoas, entrei em um acordo com meu ex-marido pra ele cuidar deles pra mim, enquanto eu faço o meu trabalho, que pra ele eu... eu trabalho com a minha família, que na verdade eu até trabalho mesmo. Eu saio por aqui, mas faço as vendas dos meus negócios também, pra dá uma renda a mais (Duda - grifos meus).

A separação e abandono do marido somados à falta de condição financeira de sustentar as crianças e ao medo de deixar os filhos com outras pessoas fizeram com que ela entregasse as crianças ao ex-marido. Poderia ser pensado que, como uma mãe exemplar que diz ser, Duda não poderia deixar os filhos passarem necessidade e, por isso, mesmo longe das crianças, ela optou por entregar a guarda ao ex-marido, evidenciando o quão preocupada e zelosa ela é. Duda busca a comprovação de que é uma mãe dedicada quando diz na SD 03 que está na prostituição pelos filhos, que são o seu foco, e que busca o melhor para eles, exclusivamente. Ela, assim, se apresenta como uma mãe digna, que se encaixa no que é estabelecido socialmente para o papel materno. Para o ex-marido, amigos e alguns familiares, Duda trabalha com a família e cuida de outros negócios; é esse outro olhar que ela também tenta repassar ao interlocutor no momento da entrevista quando diz "que na verdade eu até trabalho mesmo. Eu saio por aqui, mas faço as vendas dos meus negócios também”. Ela até pode ser x (garota de programa), mas também é y (trabalha com a família, possui outros negócios) e é atrás desse y que ela se esconde socialmente, perante os filhos, ex-marido e demais conhecidos. Mais uma vez, percebese que se as justificativas a redimissem, ela não precisaria usar y para negar ou esconder sua condição de $\mathrm{x}$.

Hoje é comum ver casos de pais que, sozinhos ou com outra esposa, são responsáveis pela guarda dos menores. Entretanto, há uma memória que diz ser mais conveniente que a mulher cuide das crianças, que o lar é o seu lugar e que ela é destinada ao casamento e ao cuidado doméstico. O que se quer dizer é que essa memória age no sentido de impor que essas mulheres (como as outras) sejam as responsáveis pela educação das crianças; e pelo seu sustento na ausência do pai. Como mães exemplares que assumem a responsabilidade de cuidar dos filhos, o que lhes foi imputado socialmente, elas precisam criá-los de uma forma ou de outra.

Alguns sentidos perpetuam e ratificam essa memória. Segundo o Código Civil de 1916, utilizado até 2001 em paralelo com a Constituição de 1988, quando o casal realiza o divórcio, a guarda é prioritária ao cônjuge inocente, Art. 326: "Sendo desquite judicial, ficarão os filhos menores com o cônjuge inocente." (Redação dada pela Lei n 4.121, de 27.8.1962) (BRASIL, 1916). Segundo o Artigo $326, \$ 1^{\circ}$, "Se ambos os cônjuges forem culpados ficarão em poder da mãe os filhos menores, salvo se o juiz verificar que de tal solução possa advir prejuízo de ordem moral para eles." (Redação dada pela Lei no 4.121, de 27.8.1962) (BRASIL, 1916). À mãe é destinada a responsabilidade sobre os filhos. Como se percebe, as leis são a formalidade legal de discursos socialmente aceitos e praticados;

Ferraça | A maternidade e a prostituição: uma análise discursiva de entrevistas com garotas de programa 
sendo assim, o papel da mãe como a guardiã dos filhos é, no imaginário social, algo fortemente marcado e essa memória é ratificada por instituições que mantêm esses valores, como a religiosa, a familiar e a jurídica.

Já o novo Código Civil de 2002, artigo 1.583, diz que "A guarda será unilateral ou compartilhada" (Redação dada pela Lei n 11.698 , de 2008) (BRASIL, 2002), substituindo os artigos anteriores. A lei pode mudar, mas não instaura práticas e discursos, ela não rompe com a eficácia material do imaginário (PÊCHEUX, 1997). E, por isso, mesmo com as alterações, ainda assim o imaginário relativo ao papel materno e ao cuidado dos filhos vigora; desse modo, elas se julgam culpadas pelo que fazem, por contrariarem o discurso delineado para a mãe, mas também se apoiam nesse mesmo discurso materno e protetor para se justificarem.

Mesmo com a mudança legal recente, ainda há uma memória substancial do papel destinado à mulher e à imagem de mãe ideal, como aquela que deve ser a responsável pelo bem-estar dos filhos, com tudo o que pode advir como consequência. Considera-se que, assim como o discurso jurídico, há outros que contribuem para tornar alguns efeitos de sentido evidentes, como o patriarcal que atribui à mulher a condição de esposa que deveria dar a vida em prol do bem familiar, dedicando sua vida aos filhos e ao marido:

Ela deveria fazer o trabalho de base de todo o edifício familiar: caber-lhe-ia educar cristamente a prole, ensinar-lhes as primeiras letras e as primeiras atividades, cuidar de seu sustento e saúde física e espiritual, obedecer e ajudar ao marido (PRIORE, 1995, p. 38, grifos meus).

Afetadas pelo interdiscurso, elas se apropriam do que é dito sobre ser mãe e utilizam essa memória (claro, no jogo entre consciente e inconsciente) para justificar o trabalho escolhido. Interpeladas pela memória que lhes atribui o dever de cuidar dos filhos, as SDs revelam que elas buscam cumprir seu dever e não fogem da responsabilidade a elas imputada, nem que para isso precisem trilhar caminhos tortuosos: elas escrevem o futuro dos filhos da maneira certa. O fato de que elas poderiam ter escolhido outros caminhos, outras formas de ganhar a vida para sustentar os filhos, que não fosse por meio de programas, não é tematizado por elas e, quando é, é para ser negado, seja porque não há oportunidade ou não há vagas ou mesmo porque o salário oferecido no mercado é inferior, como elas mesmas afirmam.

Ao se valer da posição de mãe como justificativa para o que fazem, um conjunto de pré-construídos retorna: ser mãe é um dom divino, é sacrifício, privação, dedicação e amor incondicional; "ser mãe é padecer no paraíso" como repetido pelo senso comum. A tarefa árdua e, ao mesmo tempo, sublime de se sacrificar pelos filhos redime as prostitutas de seus atos, pois elas fazem o que fazem em prol de um bem maior e natural. Ou seja, ser mãe é sacrificar-se; é esse pré-construído que as torna mulheres santas e não profanas e as coloca sob o posicionamento do discurso cristão sobre a mulher, representada por Maria: "Na visão da sociedade misógina, a maternidade teria de ser o ápice da vida da mulher. Doravante, ela se afastava de Eva e aproximava-se de Maria, a mulher que pariu virgem o salvador do mundo" (PRIORE, 2006, p. 52). É o amor puro que as motiva a fazer o possível e o impossível pelos filhos, inclusive se prostituir.

Porém, não basta apenas ser mãe e se sacrificar pelos filhos; para as garotas, é necessário também afirmar que são boas mães e que, apesar de contrariar o modelo idealizado familiar, por ser o oposto da esposa prevista pelo imaginário social, encaixam-se no modelo familiar e se colocam nessa posição de acordo com o previsto, seguindo o que pode e deve ser dito, desempenhando o papel de mãe zelosa, dedicada e responsável, ainda que encontrem uma maneira diferente de fazê-lo.

Sabe-se que é recorrente na sociedade pensar na prostituta-mãe como um ser incapaz de cuidar dos filhos, como descreve Roberts (1998, p. 85): "As leis são usadas contra as prostitutas - considerando-as mães inadequadas e colocando seus filhos em instituições públicas - com a maior insensibilidade”. Movidas por fatos dessa natureza, sem que, aparentemente, tenham consciência disso, elas se defendem, afirmando que são boas mães:

(SD 05) Então, eles são alguma coisa pra pode alegrar nós por dentro, pior nós seria se nós tivesse abandonado nossos filhos, tivesse jogado na rua, alguma coisa assim. Não. Nós tamo aqui por eles. Por eles que nós tamo aqui. Então, ninguém tem que falar nada. Só que é feio minha filha sabê, minha filha com 12 anos que eu tô na zona (Carol - grifos meus). 
Ser mãe é desempenhar o papel delimitado pela formação discursiva pertencente, por isso é necessário se enquadrar no modelo de boa mãe. Na SD 05, a entrevistada diz que não abandonou os filhos e nem mesmo os jogou na rua, ela assumiu a responsabilidade que ser mãe exige, tanto que está ali no Porto das Sereias por eles. Mas não se pode esquecer que elas estão ali quando poderiam estar em outro lugar: "doméstica, diarista, babá, trabalhei de frentista de posto, garçonete, é..., nossa, isso, mais um monte de coisa, cozinheira..." (Ana Paula); no entanto, elas escolheram a prostituição.

Discursos paralelos e recentes, mas pautados num imaginário persistente que perdura pelos séculos, contribuem para a construção do discurso materno e da sua responsabilidade para com os filhos. Segundo o artigo 22 do Estatuto da Criança e do Adolescente (ECA), "[...] aos pais incumbe o dever de sustento, guarda e educação dos filhos menores, cabendo-lhes ainda, no interesse destes, a obrigação de cumprir e fazer cumprir as determinações judiciais" (BRASIL, 1990). A SD 05 desconhece e silencia a instituição jurídica desse dever judicial e desse sujeito universal do direito de os pais serem responsáveis pela guarda e cuidado dos filhos menores e ratifica a posição da boa mãe como zelosa e dedicada, tanto que, para atendê-la, ela até se prostitui. Nesse sentido, para a FD dominante, mães que não desempenham a contento seus papéis são comumente chamadas de desnaturadas, ou seja, o que não é natural e isto produz o efeito, por outro lado, de que ser mãe (assim como lhe é dada uma suposta essência) é natural e uma condição advinda de uma constituição meramente biológica.

Chama-se a atenção para o fato de que o homem pouco (ou quase nada) é mencionado. O cliente, o (ex)marido, o pai, o dono do bordel são silenciados não só pela sua ausência no discurso (até porque em alguns momentos os ex-maridos ou o dono do bordel são citados), mas, nesse caso, se trata de um apagamento político-ideológico. Ao contrário do que se pensa, o silêncio não é a caracterização do vazio, ou, por extensão, do sem-sentido. O silêncio é indício de uma totalidade significativa. O que "[...] nos leva à compreensão do vazio da linguagem como um horizonte e não como falta [...] mais se diz, mais o silêncio se instala, mais os sentidos se tornam possíveis e mais se tem ainda a dizer" (ORLANDI, 2002, p. 71). Em outras palavras, o silêncio é mais do que a ausência do som; o silêncio é, por vezes, o mascaramento, o não dito, o que fica às escuras; são os dizeres que são calados e omitidos. Para a sociedade, ainda, estão erradas essas mulheres que vendem sexo, e não os clientes ${ }^{6}$ que compram. Os clientes não precisam se justificar em relação às razões de estarem ali ou por que traem suas esposas. Não é necessário dar desculpas para algo encarado como natural, já que os instintos sexuais aflorados dos homens são aceitos, incentivados e considerados normais. Nota-se que o mesmo não ocorre para a mulher, visto que ela que não poderia expor seu desejo sexual da mesma maneira sem que fosse condenada por isso.

Quando se fala sobre a responsabilidade pela criação dos filhos, o lugar paterno pouco aparece, ele é praticamente apagado da entrevista, esse silenciamento está justamente relacionado à memória que se tem sobre a criação dos filhos, sobre quem deve estar à frente disso. Parece ainda existir na memória discursiva a perpetuação do óbvio dever feminino de ser a responsável pelos filhos, dever que parece ser diferente para o homem, pois a ele caberia primordialmente a responsabilidade pelo sustento do lar. Ainda que hoje muitos homens estejam à frente da criação ou eduquem seus filhos sozinhos, uma memória anterior sobre o dever da mulher se perpetua. Tanto que na SD 05, Carol afirma estar orgulhosa de ser efetivamente uma boa mãe e de não abandonar os filhos. Por oposição, pode-se pensar, então, que o pai os abandonou, os jogou na rua, pois apenas ela assumiu a responsabilidade de criá-los. Se elas estão vendendo o corpo pelos filhos, em prol de um bem maior, o mesmo não ocorre com a figura paterna. Diferentemente da mãe, função em que seria considerado normal sacrificar-se pelos filhos, um pai não se prostituiria pelas crianças, pelo menos não há uma memória social sobre tal prática, não é uma prática reconhecida como recorrente (no caso do homem, poderia ser pensado em práticas criminosas, que de certo modo não ferissem sua honra de macho e, em certos casos, que ressaltassem sua suposta esperteza para driblar a lei e a moral). À mãe é destinada a responsabilidade (possível e impossível) de criar as crianças. No ECA, como mostrado anteriormente, a responsabilidade pelo cuidado e bem-estar das crianças menores é dever dos pais e não só da mãe ou só do pai, mas parece ser da mulher o encargo de criar e zelar pelos filhos, tanto que pouco se fala sobre a responsabilidade do homem.

\footnotetext{
${ }^{6}$ Ainda que homens se prostituam, ainda que mulheres procurem pelos serviços de quem vende sexo, o imaginário que se tem sobre a prostituição é de uma clientela masculina, por isso toma-se como sinônimo de clientes, homens. É, de fato, uma evidência que precisa ser pensada e discutida.
} 
Por outro lado, a imagem da boa mãe sempre será enfatizada no discurso das entrevistadas: Carol reforça ser tão zelosa e dedicada com a educação das filhas que, inclusive, mesmo sendo prostituta (e talvez por sê-lo, vendo nisso uma forma de compensar a situação), demonstra uma presteza relacionada ao cuidado com as filhas que é superior à de quem é casado:

(SD 06) Meu Deus, a educação que as minhas filhas têm, acho que... filho de pessoas que são casadas, não conseguem dar a educação, tanto o dela também, a educação, a disciplina, tudo pros nossos filhos (Carol grifos meus).

Na mescla de vozes que se ouve no enunciado, percebe-se, na SD 06, que a imagem que se tem é a da família canônica, em que pai e mãe participam da educação dos filhos; por ser uma estrutura familiar ideal, somente esse modelo poderia ter êxito na educação das crianças. Mas, para Carol e Ana Paula, mesmo que elas vivam em contradição em relação ao modelo familiar vigente, elas seriam ainda melhores, ressaltando a imagem e enaltecendo o fato de serem boas mães. Além disso, outro discurso cristalizado ecoa na SD 06: o fato de serem mães solteiras e mesmo assim conseguirem proporcionar uma boa educação, melhor, inclusive que a educação que pessoas casadas poderiam ofertar. Defendem-se do estigma que recai sobre as mães solteiras, tidas, socialmente, como incapazes (financeiramente, emocionalmente) de criarem os filhos assim como o faria o casal (abençoado pelas leis divinas e sociais, o ideal a ser seguido).

Vende-se sexo pelos filhos, mas, apesar da magnitude que isso possa ter e da benevolência com que a atividade aparece descrita, a prática é destinada às sombras, já que protegê-los acarreta também esconder que são filhos da puta. Não há como fugir do estigma moralizante: elas são a puta que pariu e eles os filhos da puta:

(SD 07) É, tipo assim, eu não acho certo fazer isso na minha cidade, pras pessoas não ficarem me apontando, né? Que eu tô na noite, que eu sou isso, que eu sou aquilo. E mais pra preservar meus filhos também... (Mônica - grifos meus).

Se vender sexo pelos filhos é um ato nobre e se elas se consideram tão boas mães como afirmam, apesar de estarem na contramão do ideal (burguês, ocidental, católico) para a mulher (ser esposa, fiel e monogâmica), por que a prática é restrita à escuridão e o seu anonimato é tão essencial como elas mesmas demonstram ser? O paradoxo está no fato de que as desculpas não as absolvem perante a moral cristã, burguesa, ocidental, são apenas tentativas vãs de justificar o que fazem, tanto para com elas mesmas como para com o outro. Entretanto, apesar de serem rés confessas, as justificativas continuam sendo usadas.

Mônica, na SD 07, como toda boa mãe, ao fazer tudo pelos filhos, também esconde que é prostituta para preservá-los de serem marcados e reconhecidos como filho da puta. O insulto, ainda mais quando comprovado, desqualifica quem recebe o nome e, mais do que isso, insulta e humilha a mãe. Chamar os filhos de filho da puta é afirmar não só que a mãe se vende por dinheiro, mas também que é promíscua, pois se relaciona sexualmente com vários homens, com qualquer um. Inclusive, por ter relações com muitos homens, faz parte do imaginário que filho de prostituta é filho sem pai reconhecido: um bastardo, o que nos casos em pauta não deixa de ser verdade (em outro sentido - pai ausente). Inclusive, a partir dessa memória, as mulheres que não são prostitutas, mas que também não sabem quem é o pai do filho (mesmo as mães solteiras que já receberam esse estigma, ou, ainda, recebem), são chamadas de puta, prostituta, meretriz etc., confirmando a honra que existe na mulher que possui relações com apenas um homem e, por consequência, tem certeza da paternidade da prole.

Numa partida de futebol, por exemplo, prática predominantemente masculina, é comum ouvir o árbitro ser chamado de filho da puta, quando se equivoca, quando realiza um julgamento ambíguo ou de difícil constatação ou simplesmente quando a penalidade aplicada favorece o time adversário; é uma expressão comumente utilizada de forma ofensiva. A ofensa, nesse caso, constitui-se a partir de uma prática estigmatizada por valores e normas sociais que condena quem pratica sexo por dinheiro, por exemplo. Ser chamado de filho da puta denigre a reputação do ofendido, por meio do comportamento sexual da mãe, já que a honra, nesse caso, se relaciona com a sexualidade feminina familiar. Além disso, a imagem materna é delineada como santa e sagrada e, nessa linha, ela é incapaz de se corromper sexualmente com outros homens. Observa-se que essa relação não é feita para o pai; não existe o filho do puto; mesmo que o pai seja um homem que saia com várias mulheres diferentes, esse estigma não existe; pelo contrário, a partir 
do imaginário até se exaltaria o pai como garanhão: um Don Juan. As mães prostitutas silenciam a forma como ganham a vida para sustentar os filhos para poupá-los do vexame que é ser reconhecido como o filho da puta. Suas vozes são silenciadas pelas vozes sociais retumbantes que, ao alardear para a sociedade a condição da prostituta, fazem ecoar sobre os filhos a herança de filho da puta.

\section{CONSIDERAÇÕES FINAIS}

A maternidade, que é usada como causa maior para a defesa, torna-se, assim, o fato mais relevante para desencadear o que supostamente tais mulheres não gostariam de fazer. Porém, elas afirmam que os filhos são o seu bem maior. Duas coisas: então, eles são os principais culpados pela prostituição da mãe e mereceriam ser chamados filhos da puta, algo inaceitável para elas; ao mesmo tempo, eles são usados, de uma forma até aceitável, como culpados pela mãe fazer o que faz, em face das imposições sociais sobre o que é ser mãe. Eis uma trama complexa criada: a mãe não quer ser puta, mas o filho a obriga, ao mesmo tempo em que ela também não deseja que o estigma de filho da puta seja reconhecido. Isso também encobre o fato de que ela provavelmente gosta ou aprecia as vantagens da vida que leva, mas não pode assumir ou admitir explicitamente que escolhe estar ali em face do dinheiro que a atividade propicia, pois não deseja ser condenada socialmente.

Elas apagam o fato de que se prostituem por si mesmas também, para manterem-se financeiramente, e não se dão conta de que todas as justificativas apontadas anteriormente são a tentativa vã de buscar uma defesa por agirem em desacordo com os modelos considerados ideais. E não se trata só da sobrevivência, mas também da garantia de um determinado padrão de vida mais elevado do que o proporcionado por profissões tradicionais, a manutenção da possibilidade de acesso a bens materiais de alto custo. Elas não assumem que também estão ali porque querem, silenciando suas escolhas, mas gritam que a culpa é do mundo.

O que se percebe é que as justificativas, na verdade, não justificam que as explicações não explicam e que as razões apontadas por elas não funcionam em face de uma sociedade que segrega, ao mesmo tempo em que estimula: condena, mas abre espaço para a venda de sexo, pois é necessário dar vazão a instintos primordiais de ordem sexual que não podem, eventualmente, ser realizados em casa ou com determinadas pessoas (o sexo, sob diversas formas, é um bem de consumo que movimenta e estimula o mercado mais amplo, incentivando a compra de determinados produtos, como música, filmes, programas de TV). De certa forma, elas vivem na confluência do bem e do mal, do bom e do mau, mas prepondera sobre elas a carga pejorativa do que fazem e que atravessa os séculos, mesmo que leis tentem evitar isso.

Se as justificativas fossem plausíveis, assim como elas alegam, elas não precisariam esconder dos filhos e do mundo que se prostituem, não haveria necessidade de frequentar boates de cidade em cidade para esconder dos conhecidos o que fazem, não precisariam dizer aos familiares que trabalham com eventos, com vendas etc. Dessa forma, considerando todo o estigma que a prática possui, as entrevistadas tecem sua defesa, buscando se redimir, ainda que a desculpa ou os culpados sejam os próprios filhos.

\section{REFERÊNCIAS}

BRASIL. Código Civilde 1916. Disponível em: <http://www.planalto.gov.br/ccivil_03/leis/L3071.htm\#art1806>. Acesso em: 13 nov. 2012.

. Código Civil 2002. Brasília: Câmara dos Deputados, Coordenação de Publicações, 2002. 342 p. (Série fontes de referência. Legislação; n. 43). Disponível em: <http://www.planalto.gov.br/ccivil_03/leis/2002/L10406.htm>. Acesso em: 25 out. 2012.

Código Penal Brasileiro. [1940]. Disponível em: <http://www.planalto.gov.br/ccivil_03/decreto-lei/del2848.htm>. Acesso em: 13 nov. 2012. 
. Estatuto da criança e do adolescente (1990). Estatuto da criança e do adolescente: Lei n. 8.069, de 13 de julho de 1990, Lei n.

8.242, de 12 de outubro de 1991. - 3. ed. - Brasília : Câmara dos Deputados. Disponível em:<http://www.planalto.gov.br/ccivil_03/leis/L8069.htm>. Acesso em: 25 out. 2012.

FLICK, Uwe. Introdução à pesquisa qualitativa. Tradução de Joice Elias Costa. 3.ed. Porto Alegre: Artmed, 2009.

GIDDENS, Anthony. A transformação da intimidade: sexualidade, amor e erotismo nas sociedades modernas. Tradução de Magda Lopes. São Paulo: Ed. UNESP, 1995.

HOUAISS, Antônio; VILLAR, Mauro de Salles; FRANCO, Francisco Manoel de Mello. Dicionário Houaiss da Língua Portuguesa. Rio de Janeiro: Objetiva, 2004.

LAGAZZI, Suzy. O desafio de dizer não. Campinas: Pontes, 1988.

ORLANDI, Eni Puccinelli. Análise de discurso: princípios e procedimentos. 3.ed. Campinas, SP: Fontes, 2001.

As formas do silêncio: no movimento dos sentidos. Campinas: Edunicamp, 2002.

PÊCHEUX, Michel. Semântica e discurso: uma crítica à afirmação do óbvio. Tradução de Eni Puccinelli Orlandi. 3. ed.. Campinas: Editora da Unicamp, 1997.

PRIORE, Mary Del. História das mulheres no Brasil. São Paulo: Contexto, 2006.

ROBERTS, Nickie. As prostitutas na história. Tradução de Magna Lopes. Rio de Janeiro: Record: Rosa dos Tempos, 1998. 